\title{
Thermostabilisation of Human Serum Butyrylcholinesterase for Detection of its Inhibitors in Water and Biological Fluids
}

\author{
Lakshmanan Jaganathan and Rathanam Boopathy* \\ Department of Biotechnology, Bharathiar University, Coimbatore - 641 046. India
}

\begin{abstract}
The ability of gelatine-trehalose to convert the normally fragile, dry human serum BChE into a thermostable enzyme and its use in the detection of cholinesterase inhibitors in water and biological fluids is described. Gelatine or trehalose alone is unable to protect the dry enzyme against exposure to high temperature, while a combination of gelatine and trehalose were able to protect the enzyme activity against prolonged exposure to temperature as high as $+50^{\circ} \mathrm{C}$. A method for rapid, simple and inexpensive means of screening for cholinesterase inhibitors such as carbamates and organophosphates in water, vegetables and human blood has been developed.
\end{abstract}

Key words: Butyrylcholinesterase, carbamates, cholinesterase, gelatine, organophosphorus, trehalose,

\section{INTRODUCTION}

The organophosphorus (OP) and carbamate compounds are widely used in agriculture as pesticides and a select few as drugs in the treatment of certain ailments. Besides these, the highly toxic derivatives of phosphoric and phosphonic acids have a potential application as chemical warfare agents (Taylor, 1990). These compounds work by inhibiting the enzyme acetylcholinesterase (AChE, EC 3.1.1.7), allowing acetylcholine to accumulate in central and peripheral synapses and over-stimulate the post-synaptic cells (Ecobichon, 1991). Under such extreme conditions this would lead to 'cholinergic crisis', which can be fatal (Padilla et al., 1995). Due to indiscriminate and wide spread application of pesticides in agriculture, the OPs and carbamates have found their way into the eco-system. It has been estimated that on a world wide basis, 50,000 illnesses (and a corresponding 20,000 deaths) are the result of pesticide poisoning each year (Moore et al., 1995). Hence, the detection of these cholinesterase inhibitor residues in soil, water and as residues on fruits and vegetables and also in biological fluids such as human blood is an important screening test to signal the presence of these toxic compounds. Many of the present methods for detection of these compounds includes the gas-chromatography or mass spectroscopy, which are not only timeconsuming, but expensive (Lopez \& Jones 1993; Pylypiw, , 1993). The other methods are based on the inhibition of cholinesterases by these compounds (Goodson \& Goodman, 1982; Mellet et al., 1991). Cholinesterases are fragile and have to be transported and stored at $-20^{\circ} \mathrm{C}$. For an enzyme like cholinesterase, to be used in mass screening procedure such as detection of pesticide residues, it is essential the enzyme should not loos its activity during storage or transportation. The ambient temperature at a given place can be as high as $45^{\circ} \mathrm{C}$, as in deserts. Hence stabilisation of cholinesterase should facilitate it to overcome the destabilising effect of higher temperatures.

A method has been described to thermostabilise human serum butyrylcholinesterase (BChE, EC 3.1.1.8) using a combination of gelatine and trehalose. The thermostabilised $\mathrm{BChE}$ has been demonstrated to withstand prolonged exposure to elevated temperatures. The stabilised $\mathrm{BChE}$ finds application in the detection of cholinesterase inhibitors in environmental and biological samples rapidly, with minimal and simple equipment.

\footnotetext{
* Author for correspondence
} 


\section{MATERIALS AND METHODS}

Materials: Butyrylthiocholine iodide (BTCI), 5,5'-dithiobis (2-nitrobenzoic acid) (DTNB), neostigmine and eserine hemisulfate were procured from Sigma Chemical Co., St.Louis, USA. Trehalose trihydrate was obtained from Sisco Research Laboratories, India and gelatine from Qualigens fine chemicals, India. All other chemicals and reagents used were of analytical grade.

Enzyme: Out dated human plasma obtained from local blood bank served as the source of BChE. From the out dated blood, BChE was purified essentially as described earlier (Boopathy \& Balasubramainan, 1985) . Protein was measured by the method of Lowry et al using BSA as standard (Lowry et al., 1951). The enzyme activity of $\mathrm{BChE}$ was assayed according to Ellman et al (Ellman et al., 1961). The reaction mixture consisted of $100 \mathrm{mM}$ potassium phosphate buffer, $\mathrm{pH} 7.0,2 \mathrm{mM}$ DTNB, $3 \mathrm{mM}$ BTCI and an aliquot of the enzyme in a total volume of $0.5 \mathrm{ml}$. After incubation for $5 \mathrm{~min}$ at $37^{\circ} \mathrm{C}$, the reaction was terminated by the addition of $0.5 \mathrm{ml}$ of 0.5 $\mathrm{mM}$ eserine hemisulfate.

Table 1: Effect of gelatine/trehalose on the stability of BChE at $37^{\circ} \mathrm{C}$

\begin{tabular}{|c|c|c|}
\hline Stabiliser & $\%$ concentration $(\mathrm{w} / \mathrm{v})$ & $\begin{array}{l}\% \text { activity } \\
\text { remaining } \\
\text { after day } 15\end{array}$ \\
\hline \multicolumn{2}{|c|}{ No additive } & 22 \\
\hline \multirow[t]{5}{*}{ Gelatine } & 0.1 & \\
\hline & 0.2 & 54 \\
\hline & 0.3 & 80 \\
\hline & 0.4 & 87 \\
\hline & 0.5 & 92 \\
\hline \multirow[t]{5}{*}{ Trehalose } & 1 & 38 \\
\hline & 2 & 51 \\
\hline & 3 & 72 \\
\hline & 4 & 84 \\
\hline & 5 & 87 \\
\hline
\end{tabular}

The activity of the enzyme preparation stored at $20^{\circ} \mathrm{C}$ is taken as $100 \%$ (control). Results are given as $\%$ of the control activity.

The yellow colour developed was then read at $412 \mathrm{~nm}$ in a Pharmacia LKB- Ultraspec III spectrophotometer. One unit of esterase activity is $1 \mu$ mole of thiocholine formed/min under the standard assay conditions $\left(\varepsilon_{\mathrm{m}}=136,000\right)$.

Stabilisation of BChE: Different concentrations of gelatine or/and trehalose in 20 $\mathrm{mM}$ potassium phosphate buffer, $\mathrm{pH} 7.0$ was added to BChE. Aliquots of $20 \mu \mathrm{l}$ (each containing $65 \mathrm{ng} \mathrm{BChE}$ protein) was taken in eppendorf tubes and concentrated (lyophilised) in a Speed Vac concentrator. The enzyme was then stored at $\quad-20^{\circ} \mathrm{C}, 37^{\circ} \mathrm{C}$ and $50^{\circ} \mathrm{C}$ and after fixed time periods, assayed for its esterase activity. The dry BChE preparation was reconstituted in the enzyme assay buffer system and the reaction was initiated by the addition of BTCI. The activity of the enzyme preparation stored at $-20^{\circ} \mathrm{C}$ was taken as $100 \%$. Relative to this, the activities of enzyme preparations stored at $37^{\circ} \mathrm{C}$ and $50^{\circ} \mathrm{C}$ were calculated.

Sample preparation: Stock solutions of different cholinesterase inhibitors, dichlorvos, diisopropyl-phosphofluoridate (DFP), monocrotophos, eserine hemisulfate and neostigmine bromide, were prepared using Millipore-filtered water and stored at $-20^{\circ} \mathrm{C}$. Whenever required, the stock solutions were equilibrated to ambient temperature and diluted in series to yield the appropriate standard solutions.

Tomato was processed as received. A $50 \mathrm{~g}$ portion of tomato was placed in a tissue homogeniser and blended for 20-30 s. The juice obtained was filtered through a sieve and different known amount of pesticides were added directly to the filtrate for analysis.

Blood was obtained from volunteers using a heparinised syringe. To $500 \mu \mathrm{l}$ of the sample, known amount of cholinesterase inhibitor was added and incubated for $10 \mathrm{~min}$ at $37^{\circ} \mathrm{C}$. Immediately thereafter, the blood was quenched in ice-cold dilute perchloric acid $(0.2 \mathrm{M}, 2 \mathrm{ml})$. The mixture was agitated briefly with a vortex mixture to complete deprotenization. The blood/perchloric acid was then at once neutralised with a stochiometric amount of sodiumhydrogencarbonate $(0.0504 \mathrm{~g}$ solid $)$. After agitation on a vortex mixture, the mixture was centrifuged at $3000 \mathrm{~g}$ for $15 \mathrm{~min}$ at $4^{\circ} \mathrm{C}$ to 
remove precipitated proteins. Aliquots of the supernatant $(50 \mu \mathrm{l})$ were taken for analysis (Loke et al., 1998).

Sample containing cholinesterase inhibitors were incubated with the stabilised BChE, that was reconstituted in the assay mixture, for 10 $\min$ at $37^{\circ} \mathrm{C}$. Thereafter, the reaction was initiated by the addition of BTCI and the residual activity measured as described above.

\section{RESULTS AND DISCUSSION}

The stabilising effect of gelatine or trehalose on $\mathrm{BChE}$ is shown in Table 1. Lyophilised $\mathrm{BChE}$ without stabiliser lost more than $75 \%$ of its activity upon storage at $37^{\circ} \mathrm{C}$ for 15 days. A 80$90 \%$ of the activity was observed with trehalose $(5 \%)$ or gelatine $(0.5 \%)$, indicating that none of the stabilisers independently could protect $100 \%$ of the BChE activity. However, a combination of gelatine $(0.1 \%)$ and trehalose $(5 \%)$ facilitated a $100 \%$ protection at all storage temperatures, for prolonged periods, even as long as 70 days (Table 2). This effect of stabilisation appears to be a synergetic action of gelatine and trehalose. Unlike DNA restriction endonucleases and acid proteases

Table 2: Effect of gelatine and trehalose coprotection on the thermostability of $\mathrm{BChE}$

\begin{tabular}{|c|c|c|c|}
\hline \multirow[t]{3}{*}{ Days } & \multirow{3}{*}{$\begin{array}{l}\text { Temp. } \\
\left({ }^{\circ} \mathrm{C}\right)\end{array}$} & \multicolumn{2}{|c|}{ Stabiliser and $\%$ activity remaining } \\
\hline & & Gelatine $(\%) 0.1$ & $\begin{array}{llll}0.1 & 0.1 & 0.2 & 0.2\end{array}$ \\
\hline & & Trehalose $(\%) 1$ & $\begin{array}{llll}2 & 5 & 5 & 5\end{array}$ \\
\hline \multirow[t]{2}{*}{0} & 37 & 100100 & 100100100 \\
\hline & 50 & 100100 & 100100100 \\
\hline \multirow[t]{2}{*}{15} & 37 & 96 & 100100100 \\
\hline & 50 & 94 & 100100100 \\
\hline \multirow[t]{2}{*}{35} & 37 & 93 & 100100100 \\
\hline & 50 & 91 & 100100100 \\
\hline \multirow[t]{2}{*}{70} & 37 & 87 & 100100100 \\
\hline & 50 & 83 & 100100100 \\
\hline
\end{tabular}

The activity of the enzyme preparation stored at $20^{\circ} \mathrm{C}$ is taken as $100 \%$ (control). Results are given as $\%$ of the control activity.

(Colaçc et al., 1992; Palvannan et al., 1998), $\mathrm{BChE}$ seem to require the co-protection from gelatine, apart from trehalose. All further analysis for cholinesterase inhibitors were carried out with

Table 3: Detection of organophosphorus cholinesterase inhibitors in water.

\begin{tabular}{lcc}
\hline Inhibitor & $\begin{array}{c}\text { Concentration } \\
(\mu \mathrm{g} / \mathrm{l})\end{array}$ & $\%$ activity remaining \\
\hline Dichlorvos & 50 & 2 \\
& 10 & 12 \\
& 2 & 77 \\
& 1 & 89 \\
& 0.2 & 92 \\
DFP & 50 & 1 \\
& 10 & 7 \\
& 5 & 24 \\
& 1 & 73 \\
& 0.5 & 80 \\
& 0.1 & 92 \\
& 0.05 & 97
\end{tabular}

$\begin{array}{rr}\text { Monocrotophos } 50 & 4 \\ 10 & 18 \\ 5 & 39 \\ 1 & 71 \\ 0.5 & 90 \\ 0.1 & 97\end{array}$

The activity of the stabilised enzyme without any inhibitor is taken as $100 \%$ (control). Results given as $\%$ of the control activity.

BChE (65 ng) stabilised with $0.1 \%$ gelatine and $5 \%$ trehalose in a total volume of $20 \mu \mathrm{l}$ and lyophilised.

Inhibitors of cholinesterases as pesticides are widely used in agriculture. The detection of pesticides residues in water and vegetable is important, because if the contamination is above the tolerance limit, would cause toxicity leading to 'cholinergic crisis'. The results obtained from analysis of the pesticides, dichlorvos, DFP and monocrotophos in water using stabilised $\mathrm{BChE}$ is given in Table 3. The sensitivity is not identical for all the inhibitors. This difference in sensitivity depends on the potency of the inhibitors to inhibit

BChE, which in turn depends on the structure of the individual inhibitors. By defining the 'detection limit' as a concentration of pesticide 
that produces a significant inhibition of $20 \%$ of the BChE activity, this limit was $2 \mu \mathrm{g} / \mathrm{l}, 0.5$ $\mu \mathrm{g} / \mathrm{l}$ and $1 \mu \mathrm{g} / \mathrm{l}$

Table 4: Detection of organophosphrous cholinesterase inhibitors in tomato juice

\begin{tabular}{lcc}
\hline Inhibitor & $\begin{array}{c}\text { Concentration } \\
(\mu \mathrm{g} / \mathrm{l})\end{array}$ & $\%$ activity remaining \\
\hline Dichlorvos & 50 & 6 \\
& 10 & 20 \\
& 2 & 78 \\
& 1 & 90 \\
& 0.2 & 95
\end{tabular}

DFP

$\begin{array}{rr}50 & 1 \\ 10 & 2 \\ 5 & 10 \\ 1 & 47 \\ 0.5 & 77 \\ 0.1 & 88 \\ 0.05 & 93\end{array}$

$\begin{array}{rr}\text { Monocrotophos } 50 & 2 \\ 10 & 13 \\ 5 & 42 \\ 1 & 68 \\ 0.5 & 84 \\ 0.1 & 90\end{array}$

The activity of the stabilised enzyme without any inhibitor is taken as 100\% (control). Results are given as $\%$ of the control activity.

for dichlorvos, DFP and monocrotophos respectively. In Table 4, the results obtained from analysis of the pesticides in tomato juice are given. As evident from Tables 3 and 4, the sensitivity of the test is similar when the pesticides were analysed in water or tomato juice. There is no interference on the analysis of these compounds in tomato juice. In clinical practice, the most commonly prescribed cholinesterase inhibitors are the carbamates eserine and neostigmine for the treatment of Alzheimer's disease and myasthenia gravis (Taylor, 1990). The screening for the residues of these drug in blood is now one of the most important tests to minimise the consequence of side-effects associated with these drugs. The data in Table 5 shows the results obtained from the analysis of eserine and neostigmine in water. The detection limit was found to be 0.5 $\mu \mathrm{g} / \mathrm{l}$ and $5 \mu \mathrm{g} / \mathrm{l}$ for eserine and neostigmine respectively. In order to screen for these drugs in blood using the enzymatic method, it

Table 5: Detection of cholinesterase inhibitor drugs in water

\begin{tabular}{ccc}
\hline Inhibitor & $\begin{array}{c}\text { Concentration } \\
(\mu \mathrm{g} / \mathrm{l})\end{array}$ & $\%$ activity remaining \\
\hline Eserine & 1000 & 5 \\
& 50 & 35 \\
& 5 & 59 \\
& 1 & 78 \\
& 0.5 & 81 \\
& 0.1 & 94
\end{tabular}

$\begin{array}{ccc}\text { Neostigmine } & 400 & 21 \\ & 50 & 56 \\ & 20 & 70 \\ & 5 & 79 \\ & 1 & 66\end{array}$

The activity of the stabilised enzyme without any inhibitor is taken as $100 \%$ (control). Results are given are $\%$ of the control activity.

is essential that interference arising from blood $\mathrm{AChE}$ and BChE must be removed. This was achieved by acid-induced deprotenisation followed by neutralisation of the quenched mixture to minimise $\mathrm{pH}$-induced interference on the enzymatic assay. Two types of samples, inhibitors in Millipore-filtered water and blood were analysed by the above quenching method to distinguish interference arising from $\mathrm{pH}$ and resolubilised proteins. The results were repeated three times and is given in Table 6. The results obtained with perchloric acid/water and perchloric acid/blood were similar. Thus, it is possible to screen for Cholinesterase inhibitors in whole blood utilising stabilised $\mathrm{BChE}$ without interference from the components of the blood.

The procedure presented here, has demonstrated the ability of the simple association of gelatine and trehalose to convert $\mathrm{BChE}$ into a thermostable enzyme. The stabilised enzyme can withstand elevated temperature, as high as $50^{\circ} \mathrm{C}$ for prolonged periods, at least up to 70 days without loss in activity. The eppendorf 
tubes containing BChE (65 ng in $20 \mu \mathrm{l}$ ) along with $0.1 \%$ gelatine and $5 \%$ trehalose can be prepared and lyophilised in advance and stored at room temperature itself.

Table 6: A comparative analysis of carbamate drugs in perchloric acid/water and perchloric Acid/blood

\begin{tabular}{|c|c|c|c|}
\hline \multirow{3}{*}{$\begin{array}{l}\text { Drug } \\
\text { acid/ }\end{array}$} & \multirow{3}{*}{$\begin{array}{l}\text { Conc.* } \\
\text { (ng) }\end{array}$} & \multicolumn{2}{|c|}{ Residual activity (\%) } \\
\hline & & Perchloric acid/ & Perchloric \\
\hline & & water & blood \\
\hline \multirow[t]{2}{*}{ Eserine } & 32.0 & 34 & 36 \\
\hline & 3.2 & 64 & 66 \\
\hline \multirow[t]{2}{*}{$\begin{array}{l}\text { Neosti- } \\
\text { gmine }\end{array}$} & 160 & 41 & 42 \\
\hline & 16 & 51 & 53 \\
\hline
\end{tabular}

The activity of stabilised enzyme in the absence of any inhibitor is taken as $100 \%$ (control). Results are given as $\%$ of the control. *Concentration of the drug in the assay mixture.

Further, the concentration range of cholinesterase inhibitors used in the present study were selected to span over a factor of a minimum of 250 for dichlorvos $(0.2-50 \mu / 1$ to a maximum of 10000 for eserine $(0.1-1000 \mu \mathrm{g} / \mathrm{l})$. Using such a wide range it is possible to detect even trace amounts of the inhibitors under the conditions of a typical assay. The procedure takes only $20 \mathrm{~min}$ to detect the presence of cholinesterase inhibitors in samples. In comparison to the earlier method employing dry, immobilised $\mathrm{AChE}$, which requires the samples to be incubated with the enzyme over-night, the procedure presented here is a very rapid one (Nguyen et al., 1997). The advantage of using $\mathrm{BChE}$, rather than $\mathrm{AChE}$ is that, $\mathrm{BChE}$ is extremely sensitive to OPs and carbamates. This is exemplified by the fact that, long before a person experiences clinical signs of poisoning with OPs or carbamates (due to inhibition of AChE), his serum BChE level decreases (Lockridge et al., 1987). Unlike previous methods based on immobilised cholinesterases on to solid-support, such as immobilisation on to ELISA plates, this method does not impose any steric hindrance on the stabilised enzyme, that would affect the interaction of the enzyme with the inhibitors. Moreover, immobilisation process itself can lead to destabilisation of the enzyme (Ulbrich et al., 1986). Lastly, converse to conventional reverse-phase column extraction with gas-chromatographic analytical techniques or mass spectroscopy, this method does not require any elaborate sample preparation procedures nor any costly equipment.

\section{ACKNOWLEDGEMENTS}

The support by Defence Research \& Development Establishment, Gwaliore, India (Project ID No. TC/05414/DRDE/ProjectDRDE-149, June, 1998) and the award of Senior Research Fellowship to L.J. by the Council of Scientific and Industrial Research, India, are gratefully acknowledged.

\section{RESUMO}

A capacidade da gelatina-trehalose em converter a frágil $\mathrm{BChE}$ do soro humano em uma enzima termoestável e seu uso na descoberta de inibidores de colinesterase em água e fluidos biológicos é apresentado. A Gelatina ou trehalose são incapazes de proteger a enzima seca BchE do soro humano contra exposição a elevadas temperaturas, enquanto que uma combinação de gelatina e trehalose são capazes de proteger a atividade de enzima contra exposição prolongada a temperaturas elevadas e da ordem de $50^{\circ} \mathrm{C}$. Um método barato, simples e rápido de screening para inibidores de colinesterase tal como carbamatos e organofosfatos em água, verduras e sangue humano foi desenvolvido.

\section{REFERENCES}

Boopathy, R. and Balasubramanian, A.S. (1995), Chemical modification of bifunctional human serum pseudocholinesterase: Effect on the pseudocholinesterase and aryl acylamidase activities. Eur J Biochem., 151, 351-360

Calaço, C., Sen, S., Thangavel, M., Pinder, S. and Roser, B. (1992), Extraordinary stability if enzymes dried in trehalose: Simplifie 
molecular biology. Bio/Technol., 10, 10071011

Ecobichon, D.J. (1991), In-Casarett and Doull, $4^{\text {th }}$ edn., eds. M.O. Amdur, J. Doull and C.D. Klassen. Pergamon, New York, pp.565-622

Ellman, G.L., Courtney, K.D., Andres, V. and Featherstone, R.M. (1961), Biochem Pharmacol., 7, 88-95

Goodson, L.H. and Goodman, A.G. (1992), Stabilisation of cholinesterase detector kit using stabilised cholinesterase, and methods of making and using the same. U.S. patent A4, 324,858; Apr. 12,

Lockridge, O., Bartels, C.F., Vaughan, T.A., Wong, C.K., Norton, S.E. and Johnson, L.L. (1987), Complete amino acid sequence of human serum cholinesterase. J Biol Chem., 262, 549-557

Loke, W.K., Karlsson, B., Waora, L., Göransson, A. and Cassel, G.E. (1998), Enzyme-based microassay for accurate determination of soman in blood samples. Anal Biochem., 257, 12-19

Lopez, A.V and Jones, T.L. (1993), Interlaboratoy study of a thermospray-liquid chromatography/mass spectrometric method for selected N-methyl carbamates, N-methyl carbamoyloximates, and substituted urea pesticides. J AOAC Int., 76, 1329-1343

Lowrey, O.H., Rosebrough, N.J., Farr, A.L. and Randall, R.L. (1951) Protein estimation with the folin phenol method. J Biol Chem., 193, 265-275

Mellet, M., Hirth, C. and Pemy, A. (1991) Detection de la famille des organophosphores et/ou des carbamates, en milieu aqeux. $F R$ 2,677,373-A; July 07

Moore, D.H., Clifford, C.B., Crawford, I.T., Cole, G.M. and Baggett, J.M. (1995), Review of nervegas inhibitors and reactivators of acetylcholinesterase. In-Enzymes of the Cholinesterase Family, eds. D.M. Quinn., A.S. Balasubramanian., B.P. Doctor. and P. Taylor. Plenum, New York, pp. 337-343
Nguyen, V.K., Ehret-Sabatier, L., Goeldner, M., Boudier, C., Jamet, G., Warter, J.M. and Poindron, P. (1997), Stabilization of dry immobilized acetylcholinesterase on microtitration plates for colorimetric determination if its inhibitors in water and biological fluids. Enz Microb Technol., 20, 18-23

Padilla, S., Chiappa, S., Koenigsberger, C., Moser, V. and Brimijoin, S. (1995), Pepeated dosing with chlorpyrifos increases acetylcholinesterase immunoreactivity in rat brain. In- Enzymes of the Cholinesterase Family, eds. D.M. Quinn., A.S. Balasubramanian., B.P. Doctor. and P. Taylor. Plenum, New York, pp.337-343

Palvannan, T., Thangavelu, A.U., Jayaprakasam, M. and Boopathy, R. (1998), Extrathermostabilization of aspartyl protease from Rhizomucor pusillus by sugars: Stabilizing role of C-2 $\alpha$ hydroxyl groups of sugars. J Scienti Indust Res., 57, 625-628

Pylypie, H.W. (1993), Rapid gas chromatographic method for the multiresidue screening of fruits and vegetables for organochlorine and organophosphate pesticides. J Ass Off Anal Chem., 76, 13691373

Taylor, P. (1990), Anticholinesterase agents. InThe Pharmacological Basis of Therapeutics, $8^{\text {th }}$ edn. Eds. A.G. Gilman., T.W Roll., A.S. Nies. And P.Taylor. Pergamon, New York, pp. 131-149

Ulbrich, R., Schellenberg, A. and Damerau, W. (1986), Studies on thermal inactivation of immobilized enzymes. Biotechnol Bioeng., 28, 511-522 